\title{
Integration of EFQM Excellence Model in RTU Development Strategy: Pilot Project Review
}

\author{
Arturs Zeps ${ }^{1}$, Juris Iljins ${ }^{2}$, Leonids Ribickis ${ }^{3}$ \\ Riga Technical University, Riga, Latvia \\ E-mails: ${ }^{1}$ arturs.zeps@rtu.lv; ${ }^{2}$ juris.iljins@rtu.lv; ${ }^{3}$ leonids.ribickis@rtu.lv
}

Received 10 February 2017; accepted 07 April 2017

\begin{abstract}
Research described in this article provides analysis of potential improvements gained to management process of higher education institutions and strategic planning by applying EFQM model and European Standarts and Guidelines (ESG). This research indicates the most crucial process elements of strategic planning in higher education institutions. Authors have analyzed pilot project where the EFQM excellence model and ESG are applied to the process of the strategic planning. Based on Riga Technical University's pilot project this article describes the role of EQFM excellence model and its impact on reaching the strategic targets set by the higher education institution. Authors have analysed and within focus groups explored the EFQM excellence model and ESG, identifing most critical aspects and facotrs of application process to strategic planning and quality assurance. Based on lessons learned authors have suggested a set of activities Riga Technical University should introduce to improve the strategic planning, structure of internal processes and quality management.
\end{abstract}

Keywords: strategy, internationalization, University, Quality assurance, development, EFQM model.

JEL Classification: P41.

Conference topic: Contemporary Issues of Economics and Management Studies: Problems and Perspectives.

\section{Introduction}

According to Michael E. Porter strategy is the process of choosing and performing the activities different from the rivals. If this is not the primary goal of creating the strategy, then it becomes just a marketing slogan that does not withstand the competition (Porter 1996). Strategy as a path for development is important for all kinds of organizations. This explains why strategy for any organization must be developed with dedication, proper attention and allocation of time and recourses. This goes for all organizations and Universities are no exception. Although Universities as other organizations can develop their strategy based on commonly used principles, it is important to differentiate themselves from other higher education institutions in the region and create a new unique niche. Choosing University's future development direction can be accomplished based on existing typology of institutions. Although there are many different typologies used in defining the different types of Universities, each University must find its own mission and purpose of existing.

ISO 9000:2015 defines that adaptation of a quality management system is strategic decision for an organization that can help to improve its overall performance and provide a sound basis for sustainable development initiatives. ISO 9000 defines as "part of quality management focused on providing confidence that quality requirements will be fulfilled". Nowadays more important is becoming Quality Assurance in Higher Education in internal or external evaluation. The EFQM (2013) (European Foundation Quality Management Excellence Model is based on a set of European values, first expressed in the European Convention on Human Rights (1953) and the European Social Charter (revised in 1996). EFQM is committed to help organizations drive improvement through the use of the EFQM Excellence Model, a comprehensive management framework used by over 30,000 organizations in Europe. EFQM Excellence Model provides a holistic view of the organization and it can be used to determine how these different methods fit together and complement each other. EFQM is a model that can be defined as structured leadership philosophy. For Quality assurance the Standards and Guidelines for Quality Assurance in the European Higher Education Area, also known as the European Standards and Guidelines (ESG), are the basis for quality assurance in the European Higher Education Area (EHEA). These standards are crucial and have significant impact on structure, form, content, delivery and important things how study process is structured in universities. Riga Technical University (RTU) has integrated EFQM excellence model structure, ESG within its Strategy and strategic planning. This article is a review of already

(C) 2017 A. Zeps, J. Iljins, L. Ribickis. Published by VGTU Press. This is an open-access article distributed under the terms of the Creative Commons Attribution (CC BY 4.0) License, which permits unrestricted use, distribution, and reproduction in any medium, provided the original author and source are credited. 
established process and focus integration of EFQM excellence model and ESG in RTU development strategy. Pilot project was carried out with obtained results and additional focus groups with stakeholders were carried out to get better feedback. This integration of methods and models proposed in artivle is called RTU Excellence approach.

\section{Role and process of strategic planning in higher education institutions}

Strategic planning can be used as a tool for University development and it has been used not only in individual organization and national level, but also in much broader scope. For universities the question is not only about how to create their own strategy, but how to incorporate whole economies needs into the strategy, thus it could provide benefit through new graduates, innovations and scientific discoveries. Strategy sets development direction for Universities many years ahead. Some Universities set their strategic aims to become the leading University in the country, region or even the whole world; others differentiate themselves by defining the field they want to excel in. Technical Universities tend to set as their strategic goals development of new innovations, promotion of creativity and technology transfer processes. Strategy for University must be made with detailed Action Plan that guides University towards its strategic aims and shows what the exact steps to achieve the defined targets are.

Strategy defines a path for organizational development. The major goals are included in the core strategy document, but wider range of indicators can be defined in the activity plan (Kaplan, Norton 2007). Many organizations fail to use strategy as a tool to plan their future or implement just the first part of strategic planning - develop the strategy, disregarding the implementation part. That's why many authors have looked into the question on how to create a strategy development process more efficient and achieve better results in strategy implementation phase. Careful and planned approach to execution is important for successful strategy implementation, and that is the factor on which organizations fail the most (Blahová, Knápková 2011). As well there are many approaches that recommend using such practices as involving employees in strategy development and creating financial incentives for units and employees to achieve better results during strategy implementation phase. It means dialogue must be created between all levels of organization through the strategy development process to foster strategic thinking and find the real niche of the company, define clear competitive advantage and create steps for reaching the desired aims. Research done by Rapert, Velliquette, and Garretson (e.g. Rapert et al. 2002) reviels that reaching internal consensus allows organizations to achieve better financial results and increases efficiency. Additionally, many authors define that management is responsible for developing and sharing the vision, encouraging innovativeness, supporting employee efforts and involving employees in decision-making process (Niehoff et al. 1990).

To define general strategic goals university must have a clear understanding of what it needs to deliver upon and perform gap analysis to understand where it currently is (Whitwam 2009). Along with general strategic goals, management is recommended to define the horizontal priorities - areas of tasks, which will allow University reaching the aims of core priorities. Horizontal priorities can be grouped in such sections as - organizational activities; international activities; financial activities, infrastructure development activities and other - thus defining what University must do to reach the aims of core directions. Each section should have subsections - university level tasks, study process tasks, research tasks, innovation process tasks. Such groups of horizontal priorities should as well be no more than 3-6 and they should be incorporated in the core processes as shown in Figure 1.

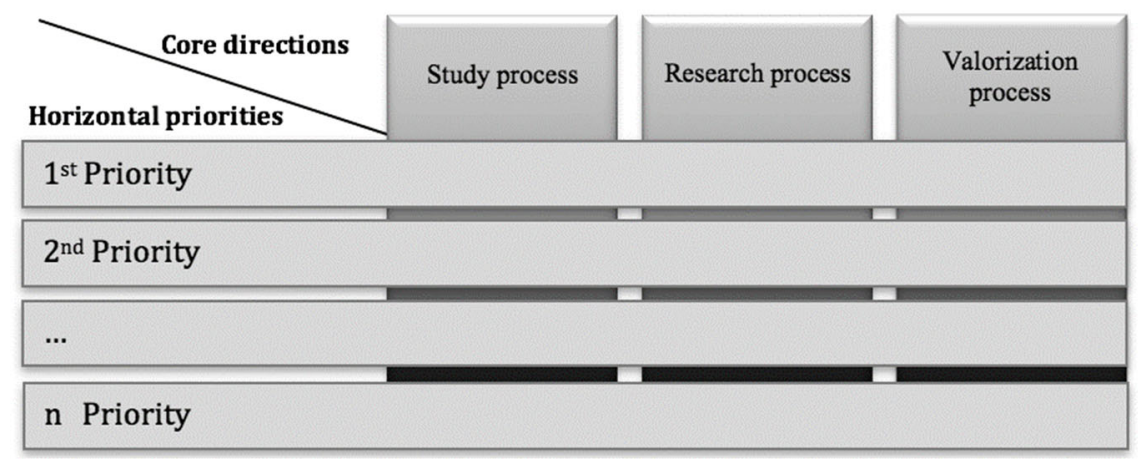

Fig. 1. Incorporation of horizontal priorities in the strategy (Source: author's)

Figure 1 as well indicates how University can set valorization as one of its core directions or goals and set horizontal priorities. By setting internationalization as one of such priorities, University is able to define factors of internationalization that promotes valorization as specific targets and find appropriate indicators. 


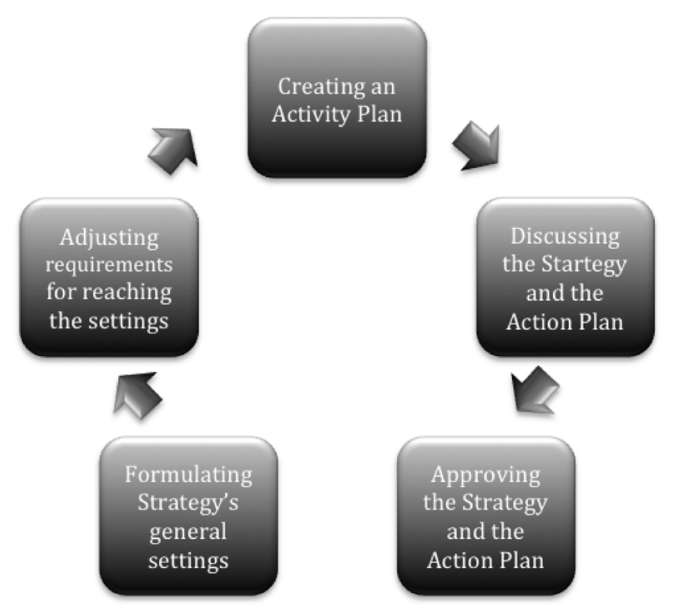

Fig. 2. Development of the Strategy and Action Plan (Source: author's)

A university by formulating core directions and defining general settings sets a direction to all further thoughts included in the strategy document. Strategic settings allow university to define where it is heading, what are the main obstacles in its way. It is followed by adjustment of requirements for reaching the settings. Management together with employees should find the answers to all general questions they will have to face during the strategy implementation process. Discussions are important for reaching consensus on strategic issues, organizational values and development plans. Here academic and scientific personnel play an important role. They must set up the aims according to today's trends and tendencies.

When the requirements for reaching the desired strategic goals are set, university must create Action Plan. Action Plan states how the organization will implement its goals, by defining clear step-by-step tasks, setting the responsible units for the results and allocating deadlines. It cannot be developed by the higher management alone, middle level managers should be involved as well. They are the ones, who can define precise activities that should be done to implement the set tasks. As well middle level management can provide the first proposal of suggested deadlines and indicators, based on which management will be able to define if the task has been done and the objectives are met. After middle level management has developed the first version of the Action Plan, it has to undergo the approval process with the higher management - they have to make sure that the set indicators and deadlines are appropriate for implementation of the strategic settings. It can lead to revision of the first version of the Action Plan making it more chalanging for the organization and employees.

Before approving the Strategy and the Action Plan, in discussions about these documents must be involved as many internal and external stakeholders as possible. After strategy reviewing process by external and internal parties' final approval is granted by the decision making body. All of the above explain what is the process of strategy development for universities (Fig. 2).

As mentioned above, detailed Action Plan guides University towards its strategic aims and shows what the exact steps to achieve the defined targets are. Based on detailed strategic targets University is able to plan clear tasks, set measurable indicators, responsible units for the expected results and clear deadlines to measure if the tasks are met. Figure 3 depicts process of setting strategic targets for units of University and elements that must be defined. Each unit and employee must know his role and responsibility for achieving organizations targets. All tasks must have indicators (should be set at the realistic growth rate) and deadlines - they ensure following the implementation process of the strategy in university.

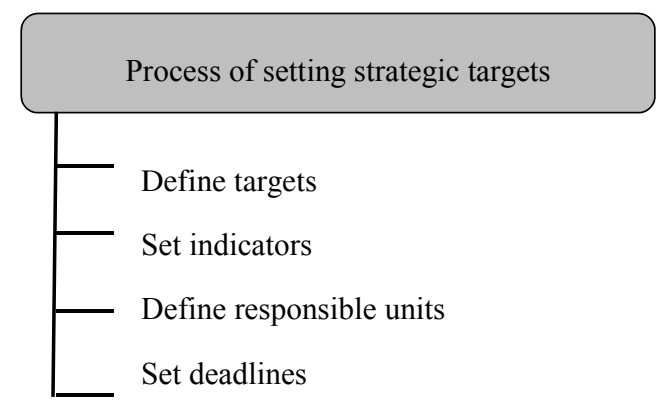

Fig. 3. Process of setting strategic targets (Source: author's) 
When the strategy has been set, for successful implementation process university must set its internal systems and procedures to control the overall implementation of the strategy. University has to establish a control mechanism to monitor the strategy and action plan execution process - what can be accomplished through the usage of appropriate IT solutions. It is recommended to apply different IT solutions to increase the successful implementation of the strategy, set targets and increase valorization potential. Introduction of IT solutions must go along with appropriate processes in University and shared value concepts from divisions and employees. Described processes of internationalization and valorization in a University can be supported by different IT systems, but the most important task for management is to set them according the strategic settings and apply in the control process.

\section{Application of EFQM model and European Standarts and Guidelines to management process}

According to Calvo-Mora et al. (2015) organizations need to establish an appropriate management system to achieve success, irrespective of the sector, size or structure. Here, the EFQM Excellence Model sets out a practical and nonprescriptive management system that allows organizations to (Suárez et al. 2014): (1) prepare a basic structure for the design, implementation and improvement of a comprehensive management system; (2) evaluate their position on the path towards excellence, identifying their strengths and weaknesses as a starting point for the establishment of strengthening and improvement plans; (3) prepare a common framework and language that favors effective communication within the structure and (4) systematically integrate the strategic planning and interest group orientation into their management. As Escrig and de Menezes (2015) points out The EFQM was launched in 1991 as a non-prescriptive framework based on nine criteria, whose present version and respective weights are depicted in Figure 4 . Each criterion encompasses several sub-criteria, thus leading to a total of 32 sub-criteria. The EFQM model was last revised in 2013 and 2015 with the aim to align the framework with current business needs and trends.

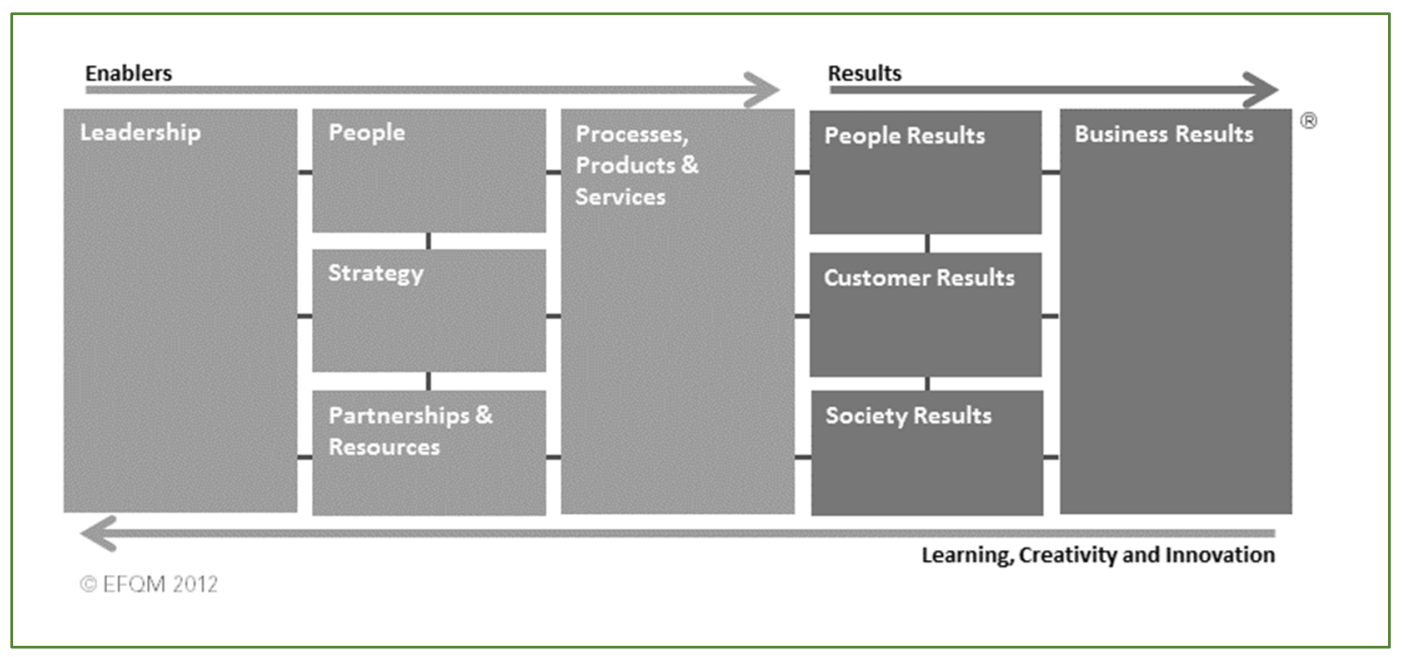

Fig. 4. The EFQM Excellence Model (Source: EFQM 2013

EFQM 2013 states, that each of the nine criteria has a definition, which explains the high level meaning of that criterion. To develop the high level meaning further each criterion is supported by a number of criterion parts. Criterion parts are statements that describe in further examples of what, typically, can be seen in excellent organizations and should be considered in the course of an assessment. Finally, below each criterion part are guidance points. Many of these guidance points are directly linked to the Fundamental Concepts mentioned earlier. Use of these guidance points is not mandatory. They are intended to give examples to aid interpretation of the criterion part. Jankal and Jankalova (2016) mention EFQM Excellence model, as the approach to assessing the excellence of business subjects is undergoing constant changes, individual areas and criteria serving for the general assessment of excellence are being changed and amended. It is based on 8 fundamental concepts of excellence (adding value for customers; creating a sustainable future; developing organizational capability; harnessing creativity \& innovation; leading with vision, inspiration \& integrity; managing with agility; succeeding through the talent of people; sustaining outstanding results).

In expert work groups organized by authors it was concluded, that on the downside self-evaluation point assessment is too complex. For organization that starts to implement the model it becomes more challenging. This is necessity to get EFQM certification. If organization peruses scoring in their self-evaluation then it becomes very difficult to communicate methodology to employees. Even if organization manages successfully to self-evaluation assessment team, then it becomes even more increasingly challenging to explain the scoring to other employees whose work is evaluated. There more complex methodology is introduced the more other employees start to distrust it. Another issues is score comparison between periods. It is highly likely that self-evaluation team will change if evaluation is done once 
every two or three years. So people will change so can perception and subjective vision on how to grade progress in criteria. If organization wants to increase its number of stars the grade methodology changes once again and scores and not comparable. So there are no real possibilities to compare obtained results on organizations performance throughout the years. This may take organizations to peruse other internal quality models and turn away from EFQM.

Goal of the Standards and Guidelines for Quality Assurance in the ESG is to contribute to the common understanding of quality assurance for learning and teaching across borders and among all stakeholders. The ESG are a set of standards and guidelines for internal and external quality assurance in higher education. The ESG are not standards for quality, nor do they prescribe how the quality assurance processes are implemented, but they provide guidance, covering the areas which are vital for successful quality provision and learning environments in higher education. In this article authors explore more ESG standards related to internal quality assurance. In RTU ESG are integrated in EFQM excellence model and deployed as quality system this combined method is called RTU Excellence approach. Research results in Table 1 represent ESG and EFQM integration in case of RTU. Authors evaluated RTU existing documentation, processes and strategy to conclude how EFQM can fit with ESG. Table 1 shows ESG standard structural representation in EFQM excellence model. When preparing EFQM self-evaluation report organizations have to reflect and prove with data and analysis that they fulfill certain EFQM sub-criteria. For future EFQM quality audit and study process accreditation authors propose extended sub-criteria list. This will help to use the same criteria evaluation and analytical documents for both - external quality control purposes (EFQM and ESG accreditation framework). ESG correspond and follow criteria that European Quality Assurance Register accreditation body members use. Table 1 shows ESG standard structural representation in EFQM excellence model.

Table 1. Internal quality assurance ESG integration in EFQM excellance model (Source: author's)

\begin{tabular}{|c|c|c|c|}
\hline Nr. & $\begin{array}{l}\text { Standards and guidelines for } \\
\text { internal quality assurance }\end{array}$ & Standard & $\begin{array}{l}\text { Corresponding EFQM } \\
\text { excellence model criteria }\end{array}$ \\
\hline 1. & Policy for quality assurance & $\begin{array}{l}\text { Institutions should have a policy for quality assurance that } \\
\text { is made public and forms part of their strategic manage- } \\
\text { ment. Internal stakeholders should develop and implement } \\
\text { this policy through appropriate structures and processes, } \\
\text { while involving external stakeholders. }\end{array}$ & $\begin{array}{l}\text { Leadership, People, } \\
\text { Strategy, people results, } \\
\text { customer results, Busi- } \\
\text { ness results. }\end{array}$ \\
\hline 2 . & $\begin{array}{l}\text { Design and approval of } \\
\text { programme }\end{array}$ & $\begin{array}{l}\text { Institutions should have processes for the design and ap- } \\
\text { proval of their programmes. The programmes should be de- } \\
\text { signed so that they meet the objectives set for them, includ- } \\
\text { ing the intended learning outcomes. The qualification re- } \\
\text { sulting from a programme should be clearly specified and } \\
\text { communicated, and refer to the correct level of the national } \\
\text { qualifications framework for higher education and, conse- } \\
\text { quently, to the Framework for Qualifications of the Euro- } \\
\text { pean Higher Education Area. }\end{array}$ & $\begin{array}{l}\text { People, strategy, Pro- } \\
\text { cesses products and ser- } \\
\text { vices. }\end{array}$ \\
\hline 3. & $\begin{array}{l}\text { Student-centred learning, } \\
\text { teaching and assessment }\end{array}$ & $\begin{array}{l}\text { Institutions should ensure that the programmes are deliv- } \\
\text { ered in a way that encourages students to take an active role } \\
\text { in creating the learning process, and that the assessment of } \\
\text { students reflects this approach. }\end{array}$ & $\begin{array}{l}\text { Processes products and } \\
\text { services, customer re- } \\
\text { sults, }\end{array}$ \\
\hline 4. & $\begin{array}{l}\text { Student admission, progres- } \\
\text { sion, recognition and certifi- } \\
\text { cation }\end{array}$ & $\begin{array}{l}\text { Institutions should consistently apply pre-defined and pub- } \\
\text { lished regulations covering all phases of the student "life } \\
\text { cycle", e.g. student admission, progression, recognition and } \\
\text { certification. }\end{array}$ & $\begin{array}{l}\text { Partnership \& resources, } \\
\text { processes products and } \\
\text { services, customer re- } \\
\text { sults, business results }\end{array}$ \\
\hline 5. & Teaching staff & $\begin{array}{l}\text { Institutions should assure themselves of the competence of } \\
\text { their teachers. They should apply fair and transparent pro- } \\
\text { cesses for the recruitment and development of the staff. }\end{array}$ & $\begin{array}{l}\text { Leadership, strategy, } \\
\text { people, partnership \& re- } \\
\text { sources, processes prod- } \\
\text { ucts and services, people } \\
\text { results. }\end{array}$ \\
\hline 6. & $\begin{array}{l}\text { Learning resources and stu- } \\
\text { dent support }\end{array}$ & $\begin{array}{l}\text { Institutions should have appropriate funding for learning } \\
\text { and teaching activities and ensure that adequate and readily } \\
\text { accessible learning resources and student support are pro- } \\
\text { vided. }\end{array}$ & $\begin{array}{l}\text { People, strategy, partner- } \\
\text { ship \& resources, pro- } \\
\text { cesses products and ser- } \\
\text { vices, customer results. }\end{array}$ \\
\hline 7. & Information management & $\begin{array}{l}\text { Institutions should ensure that they collect, analyse and use } \\
\text { relevant information for the effective management of their } \\
\text { programmes and other activities. }\end{array}$ & $\begin{array}{l}\text { Leadership, strategy, } \\
\text { processes products and } \\
\text { services, customer re- } \\
\text { sults. }\end{array}$ \\
\hline
\end{tabular}


Continued Table 1

\begin{tabular}{c|l|l|l}
\hline Nr. & $\begin{array}{l}\text { Standards and guidelines for } \\
\text { internal quality assurance }\end{array}$ & \multicolumn{1}{|c|}{ Standard } & $\begin{array}{l}\text { Corresponding EFQM } \\
\text { excellence model criteria }\end{array}$ \\
\hline 8. & Public information & $\begin{array}{l}\text { Institutions should publish information about their activi- } \\
\text { ties, including programmes, which is clear, accurate, ob- } \\
\text { jective, up-to date and readily accessible. }\end{array}$ & $\begin{array}{l}\text { People, processes prod- } \\
\text { ucts and services, people } \\
\text { results, customer results, } \\
\text { society results. }\end{array}$ \\
\hline 9. & $\begin{array}{l}\text { On-going monitoring and pe- } \\
\text { riodic review of programmes }\end{array}$ & $\begin{array}{l}\text { Institutions should monitor and periodically review their } \\
\text { programmes to ensure that they achieve the objectives set } \\
\text { for them and respond to the needs of students and society. } \\
\text { These reviews should lead to continuous improvement of } \\
\text { the programme. Any action planned or taken as a result } \\
\text { should be communicated to all those concerned. }\end{array}$ & $\begin{array}{l}\text { Leadership, strategy, } \\
\text { partnership \& resources, } \\
\text { processes products and } \\
\text { services, people results, } \\
\text { customer results, society } \\
\text { results, business results. }\end{array}$ \\
\hline 10. & $\begin{array}{l}\text { Cyclical external quality as- } \\
\text { surance }\end{array}$ & $\begin{array}{l}\text { Institutions should undergo external quality assurance in } \\
\text { line with the ESG on a cyclical basis. }\end{array}$ & $\begin{array}{l}\text { People, Strategy, Pro- } \\
\text { cesses products and ser- } \\
\text { vices, people results, } \\
\text { customer results, busi- } \\
\text { ness results. }\end{array}$ \\
\hline
\end{tabular}

This ESG standard integration in EFQM is part of wider quality management strategy where EFQM sub criteria and ESG standard guideline integration is integrated on more detailed level and presented with matrix interface. To analyses the criteria interrelation impact further research is required.

\section{Case analysis of strategy development in Riga Technical University}

Riga Technical University has created the strategy for the period of 2014-2020 and approved it by the decision of the highest level decision making body in October 2013. The integral part of the strategy is detailed action plan. That is why university has developed document that sets core priorities and detailed key performance indicators that allow following the strategy implementation process. The strategy and action plan became the real tool for developing university.

Management work group together with the Rector worked on the mission that had to express three core objectives of RTU - study process, research and innovation and commercialization process. The mission was adopted as follows "To ensure internationally competitive high quality scientific research, tertiary education, technology transfer and innovation for Latvian national economy and the society" (Riga Technical University 2013). All key targets within 3 groups are general indicators for the success of strategy implementation within year 2020.Based on the mission, the university gained the triangle that reflected the core objectives and symbolized their unity seen in Figure 5.

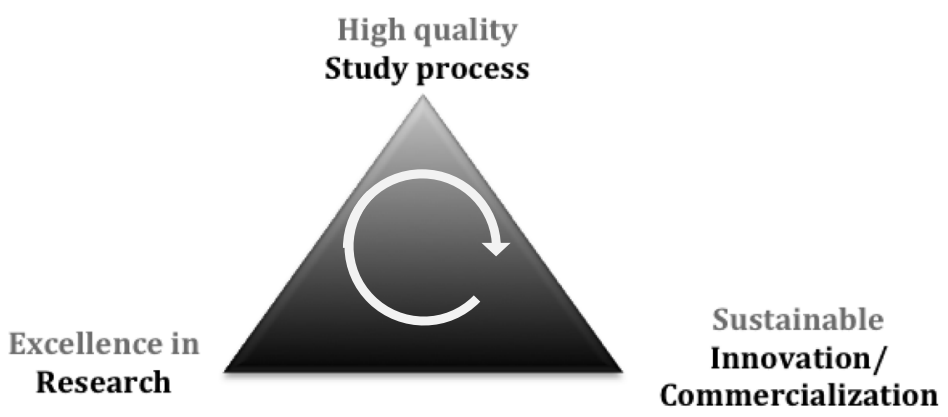

Fig. 5. Defining the core objectives for Riga Technical University (Source: author's)

Although the university acknowledged that beside study process, research and innovation and commercialization process it has to clearly state 5 horizontal priorities that cross all activities implemented within the university. Based on such setting, the work group introduced horizontal priorities - internationalization, interdisciplinary, organizational efficiency, financial efficiency and infrastructure efficiency and these priorities should have been incorporated in all 3 objectives, as seen in Figure 6. RTU uses these five horizontal priorities as a prism to see implementation of its objectives and to ensure the consummation of the mission.

The management of Riga Technical University established a two level strategy. The first level was a general university strategy and action plan approved in decision-making body defining the general development path for the 
whole university. The second level was a strategy of each faculty approved by rector defining how a faculty will excel, what will be its specialization and improvements in the study process, research and innovation.

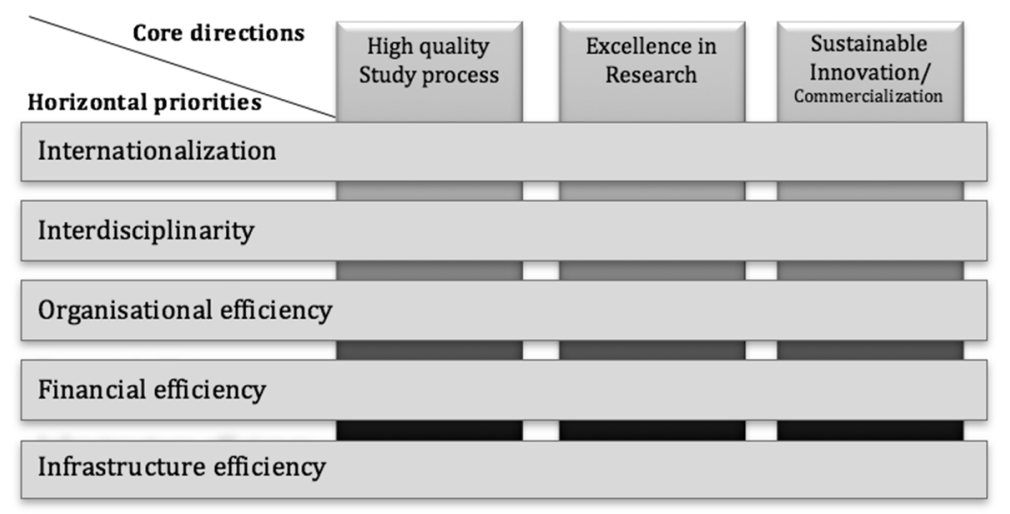

Fig. 6. Horizontal priorities for the strategy of Riga Technical University (Source: author's)

Management of RTU twice a year analyzed the implementation results of the strategy in university and faculty level, analyzing the results gained in contrary to the set targets. It was identified that some of the tasks were not defined clearly enough when RTU strategy development process was implemented for the first time. Therefore RTU underwent the strategy adjustment in 2015 - some targets were changed. The structure of the university had also changed, thus indicating the need to define responsibilities for some specific units that previously did not exist.

\section{Potential development of Riga Technical University's strategy and internal processes based on EFQM model} Existing RTU Strategy's improvement porcess according the EFQM model

Authors have analyzed application of EFQM model and European Standards and Guidelines to management process as well as developed RTU Excellence approach. Authors propose that further application of this methodology for systematic development of RTU ir important. In this approach RTU has integrated its Constitution, Strategy, Quality Assurance policy, ESG and EFQM excellence model as shown in Figure 7.

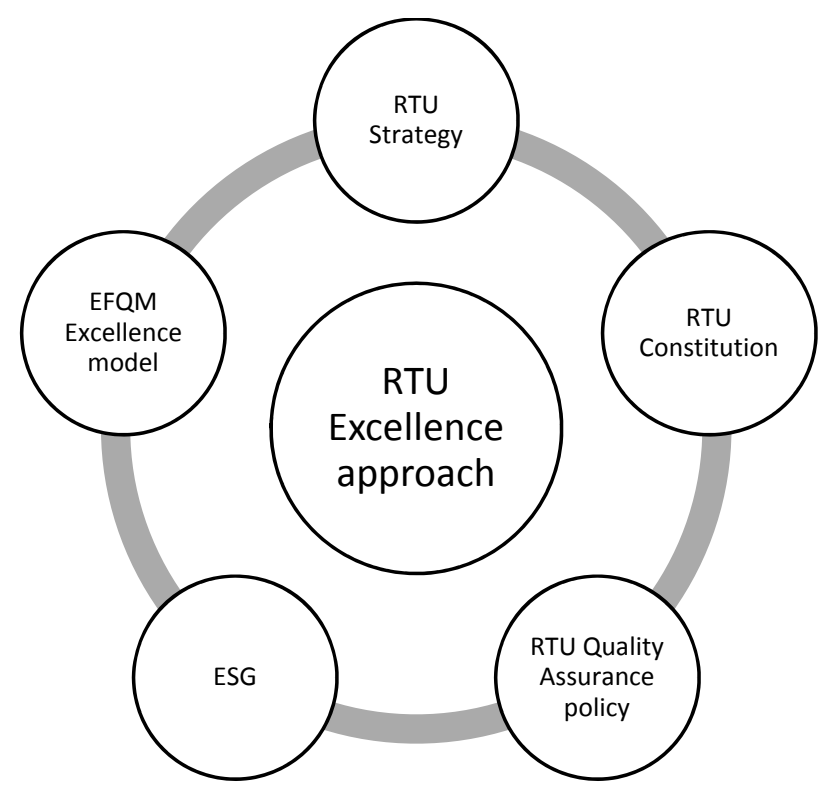

Fig. 7. RTU Excellence approach (Source: author's)

In Figure 7 main elements of RTU Excellence approach and their interaction are shown, but EFQM (2013) states that core principles behind excellent organization is adding value to customers, succeeding trough talent of people, flexible management, developing organizational capability, harnessing creativity and innovation, leading with vision, inspiration and integrity and sustaining outstanding results which leads to sustainable development. All of these principles are horizontally integrated in mentioned management tools, standards and policies. 
With implementation of this approach RTU has defined process steps needed to work towards reaching excellence. Process steps in Figure 8 show organizational process and serves as united principle for understanding quality matters in University, achieving set objectives and sustainable development. Steps are divided in planning results, proceeding with approach, implementation, assessment and refinement.

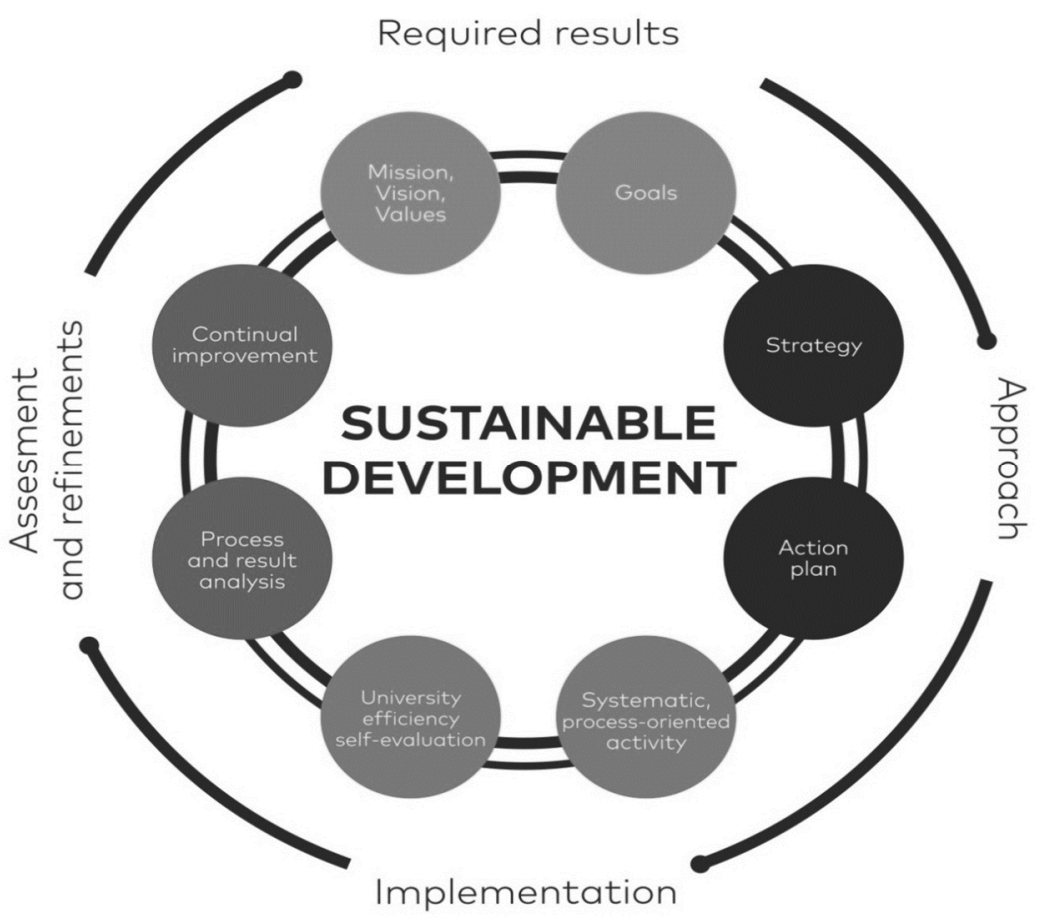

Fig. 8. RTU Excellence approach steps (Source: author's)

In reaching RTU's sustainable development goals RTU follows European Higher Education Area policy initiatives - through inclusion of society, employers, students, alumni, green policy and other stakeholder goals. Desired results of RTU Excellence approach are set based on RTU Mission, Vision and Values. They are mainly focused on setting achievable goals, developing and creating more competitive national economy through creating additional value for perspective graduates and existing students. Keeping this in mind RTU have set its goals that are implemented through RTU Strategy which focuses on high quality study process, excellence in research and sustainable valorization. Once all the strategic objectives are set, action plan was created with concrete activities how to improve university and to help achieve previously set targets. Implementation phase began with systematic process oriented review of real time data. Analyzed data are used to further enhance process or make conclusions on set targets.

Once every year university conducts self-evaluation report to look on processes and possible improvements in the future in terms of Action plan and the strategy implementation process. After self-evaluation and analysis of performance data proposals are created for management to introduce further changes for continues improvement if necessary.

\section{Further development of strategic planning at Riga Technical University and incorporation of EFQM model}

In furture authors suggest improving the process of strategic planning and introducing more sophisticated analysis of action prioritizing. After the the first analysis of strategy implementation authors suggest applying evaluation and review on current situation based on university's self-evaluation and further action prioritizing. This should be done by analyzing the existing strategic action plan and the implemented tasks. This will allow introducing bottom-up approach to achieve higher staff involvement. Method on sorting priority of action plan is proposed as shown in Table 2 .

Table 2. Action prioritizing (Source: author's)

\begin{tabular}{l|ccc}
\hline \multicolumn{1}{c}{ Action } & Importance & Urgancy & Priority group \\
\hline 1st action & 1 to 10 & 1 to 10 & 1 to $\ldots \mathrm{n}$ \\
2nd action & 1 to 10 & 1 to 10 & 1 to ...n \\
n action & 1 to 10 & 1 to 10 & 1 to ...n \\
\hline
\end{tabular}


To successfully sort prioritized actions two level process is proposed. First self evaluation implemented by middle level managers and Faculty representatives. The analysis would allow to understand how based on the Action prioritizing form seen in Table 1 middle management rates importance and urgency of actions that are included in the action plan for the next years. Then based on this analysis a rating of further activities can be developed providing Action coefficient, describing importance and urgency of each activity as seen in Formula 1.

$$
\text { Action coef. }=\text { Importance } \mathrm{x} \text { Urgency }
$$

The last part of the analysis of further activities incluced in the action plan is implement through additional reevaluation of each activity definig activities priority, thus setting it higher or lower in the next year's priority list. This should be done by higher management of the university. When management has reviewed the action plan and prioritized the actions, a new Action plan should be approved by the decision-taking institution of the university, thus approving the new work plan. To further develop this model another two changing factors should be introduced with different weighting indicators. First is needed resources to implement action. If more resources are need to implement the action, then lower should be its overall weight. Second indicator is impact which should be added. Therefore, meaning if action with high resources will have high impact that it is a good investment, if impact is low overall coefficient should be lower. To evaluate these correlations and weighting further research should be required.

\section{Conclusions}

EFQM model allows creating a valuable process for reaching universities strategic targets set in the strategy. Based on example of Riga Technical University it can be concluded that through strategy development, university must create a detailed Action plan with clear activities that should be implemented to reach the desired key performance indicators set in the strategy. This action plan should be regularly overviewed and analyzed to understand which are the most important activities since the environment both with university and outside it is changing. For implementation of this task EFQM model should be applied through defined university's excellence model, which sets the map of strategy result overview and future activity prioritizing. It is as well a tool not only of reevaluaating the strategic targets and activities that should be done to implement the strategy, but as well a great way how to involve employees in the strategy development thus providing them grater awareness of university's future development plans.

Intergration of EFQM excellence model and ESG in RTU strategic planning and RTU Excellence approach (Constitution, Strategy, Quality Assurance policy, ESG and EFQM excellence model) is important and effective tool for developing University. Using such approach University makes it possible not only to successfully achieve its strategic targets and realize its mission, but also integrate it in nowadays important concept as sustainable development. That is especially important for research and innovation universities for valorization process.

Resaerch paper on review of pilot project that integrated EFQM quality model and ESG into RTU strategy authors conclude that:

1) Authors developed joint EFQM quality and ESF subcriteria integration, that can be used jointly for external evaluation;

2) Self-evaluation as additional method for improvement of RTU efficiency can be improved;

3) Defining enablers and results in context of processes, staff, students and society was helpful to better understand how to define key performance indicators and set up action plan;

4) Involvement of middle level management and Faculty representatives has led to better understanding of quality assurance system, strategic targets and awareness of top-management objectives;

5) When employees are empowered to propose and share ideas on how to move forward with the strategic tasks they feel more involved in setting the priorities for university;

6) Further research and data is needed to analyze mid-term and long-term impact of EFQM model on implementation of university's targets.

\section{Acknowledgements}

This research has been supported by project: «EU Policies Impact to the Transformations of the Higher Education and Research System in Norway and Latvia» (agreement No NFI/R/2014/006).

\section{Disclosure statement}

The author does not have any competing financial, professional, or personal interests from other parties. 


\section{References}

Blahová, M.; Knápková, A. 2011. Effective strategic action: from formulation to implementation, in 2010 International Conference on Economics, Business and Management, IPEDR, vol. 2, Manila, Philippines, 61-65.

Calvo-Mora, A.; Navarro-García, A.; Periañez-Cristobal, R. 2015. Project to improve knowledge management and key business results through the EFQM excellence model, International Journal of Project Management 33: 1638-1651. https://doi.org/10.1016/j.ijproman.2015.01.010

EFQM Excellence Model. 2013. EFQM Publications.

Escrig, A. B; De Menezes, L. M. 2015. What characterizes leading companies within business excellence models? An analysis of "EFQM Recognized for Excellence" recipients in Spain, International Journal of Production Economics 169: 362-375. https://doi.org/10.1016/j.ijpe.2015.08.019

ISO 9000:2015. Clause 01. General. 2015. ISO 9000:2015 Online browsing platform [online], [cited 12 January 2017]. Available from Internet: https://www.iso.org/obp/ui/\#iso:std:iso:9000:ed-4:v1:en

Jankal, R.; Jankalova, M. 2016. The application of the EFQM excellence model by the evaluation of corporate social responsibility activities of companies, Procedia Economics and Finance 39: 660-667. https://doi.org/10.1016/S2212-5671(16)30313-6

Kaplan, R. S.; Norton, D. P. 2007. Using the balanced scorecard as a strategic management system, Harvard Business Review (JulyAugust).

Niehoff, B. P.; Enz, C. A.; Grover, R. A. 1990. The impact of top-management actions on employee attitudes and perceptions, Group Organization Management Journal (September), 337-352.

Porter, M. E. 1996. What is a strategy?, Harvard Business Review (November-December), 61-78.

Rapert, M. I.; Velliquette, A.; Garretson, J. A. 2002. The strategic implementation process evoking strategic consensus through communication, Journal of Business Research 55(4): 301-310. https://doi.org/10.1016/S0148-2963(00)00157-0

Riga Technical University. 2013. Strategy of Riga Technical University 2014-2020. RTU, Riga.

RTU Excellence approach. 2017. Adopted methodology at Riga Technical University.

Suárez, E. M.; Roldán, J.; Calvo-Mora, A. 2014. A structural analysis of the EFQM Model: an assessment of the mediating role of process management, Journal of Business Economics and Management 15: 862-885. https://doi.org/10.3846/16111699.2013.776627

Whitwam, D. R. 2009. Implementing effective organizational strategy, Standards and guidelines for quality assurance in the European Higher Education Area, 2015 [online], [cited 10 December 2016]. Available from Internet: http://www.charlesmore.com/cms/files/Implementing_Effective_Organizational_Strategy_ID39861.pdf 